\title{
CRIMINAL PROCEDURE AND CRIMINALISTICS
}

\author{
DOI https://doi.org/10.30525/978-9934-26-179-4-45
}

\section{ПЕРЕХРЕСНИЙ ДОПИТ У СУДОВОМУ ПРОЦЕСІ}

\author{
Гарасимів О. I. \\ кандидат юридичних наук, дочент, \\ доцент кафедри кримінального процесу та криміналістики \\ Львівський державний університет внутрішніх справ \\ м. Львів, Україна \\ Ряшко О. В. \\ кандидат юридичних наук, дочент, \\ доиент кафедри кримінального процесу та криміналістики \\ Львівський державний університет внутрішніх справ \\ м. Львів, Украӥна
}

3 усіх засобів та способів отримання доказової інформації допит $€$ найпоширенішим та водночас найскладнішим, оскільки вимагає від особи, що допитує наявності високих комунікативних навичок, знання психології людини та вміння застосувати це на практиці. Допит - це процесуальна дія, яка регламентована кримінальними процесуальними нормами та спрямована на отримання інформації, що має значення для встановлення обставин кримінального правопорушення. Кінцева мета допиту полягає в отриманні достовірних показань, які можуть бути покладені в основу процесуального рішення та підставі яких у судовому засіданні можливості прийти до висновку щодо винуватості або невинуватості особи.

У змагальному процесі перехресний допит - один 3 найважливіших засобів дослідження доказів i, без сумніву, небезпечний i для того, хто допитує. Одним необережним запитанням можна знищити плоди напрацювань всього судового процесу. В суді за участю присяжних значимість перехресного допиту зростає. Допит стає домінантою судового змагання. Звідси висновок, що ненадання права на перехресний допит може потягнути неповноту судового слідства та неприпустимість використання таких показань, що підтверджує практика ЄСПЛ. Відповідно до підпункту «сі» п. 3 ст. 6 Свропейської конвенції про захист прав людини та основоположних свобод кожний обвинувачений, як мінімум, має право допитувати свідків, які дають показання проти 
нього, або право на те, щоб ці свідки були допитані. В українському процесі це право, на жаль, належним чином не реалізовується.

Як показує судова практика, сутність та порядок прямого та перехресного допитів свідків, потерпілих викликає багато спірних питань та не $є$ однозначною. Допит цих учасників судового провадження і надалі часто проводиться за правилами, визначеними на рівні КПК України 1960 року. Бувають випадки відкритого «нехтування» нормами чинного КПК України 2012 року. Виправити ситуацію може більш розгорнута законодавча регламентація правил проведення судового допиту свідків, потерпілих, відповідні роз'яснення та рекомендації науковців та вивчення суддями, прокурорами та адвокатами міжнародного досвіду проведення прямого i перехресного допиту та позицій Європейского суду з прав людини [1, с. 67].

Навички перехресного допиту адвокат отримує через досвід участі в судах. Його ніщо не замінить. Але за цей досвід адвокати, а особливо їх клієнти, платять дорогою ціною. Однак для того щоб оволодіти мистецтвом перехресного допиту, потрібно, принаймні, знати методи крос-екзаменаторів. Показання не існують у відриві від свідка. А тому у мистецтво перехресного допиту входить вміння працювати 3 усім спектром обставин, які супроводжують речову взаємодію кросекзаменатора (допитуючого) і допитуваного у суді [2, с. 11].

Частина 2, п. 5 ст. 87 КПК зазначає, що суд зобов'язаний визнати істотним порушенням прав людини порушення права на перехресний допит. Отже, адвокат має чітку правову базу для обстоювання свого права на проведення пререхресного допиту.

У кримінальному судочинстві перехресний допит відомий як спосіб перевірки та одержання достовірних доказів. Саме під час такого допиту є реальна можливість вирішити питання щодо дискредитації особи свідка та його показань. Розрізняють наступні види перехресного допиту: первісний, повторний та додатковий.

Основним завданням перехресного допиту виявляється у тому, що він виступає як контраргумент та спростовує доводи протилежної сторони.

Погоджуємося 3 думкою, що будь-яке судження в суді тільки тоді набуває належної повноти, якщо воно підтверджено перехресним допитом. Кожна сторона повинна забезпечуватися правом на проведення перехресного допиту, навіть сама можливість його проведення вже $є$ гарантією достовірності та допустимості фактів, що встановлюються. Загальновідомим є той факт, що істиною в суді визнається результат згоди сторін, що досягається у судовому процесі, тобто квазі істина, яка може збігатися або суперечити істині об'єктивній. 
Сторона (ст. 22 КПК) здійснює захист на основі змагальності, що передбачає самостійне обстоювання своїх правових позицій. Функції обвинувачення, захисту та судового розгляду не можуть покладатися на один і той же орган чи службову особу. Захист здійснює підозрюваний або обвинувачений та його захисник. На суд покладається обов'язок створити необхідні умови для реалізації сторонами своїх прав при збереженні об'єктивності і неупередженості.

Слід наголосити, що послідовність проведення допитів повинна залежати від обставин вчиненого кримінального правопорушення та обсягу обізнаності з ними потерпілого та свідків. Суду варто в ухвалі про визначення обсягу та порядок дослідження доказів максимально повно задовольняти бажання сторін, оскільки вони грунтуються на розроблених ними правових позиціях і продуманій стратегії та тактиці проведення дослідження доказів. За чинним КПК України свідки та потерпілі допитуються за правилами прямого та перехресного допиту. Незважаючи на те, що питання проведення прямого та перехресного допиту регулюють лише положення ч.ч. 6-8 ст. 352 і ст. 353 КПК України, за цими нормами стоїть справжня революція в допиті свідків і потерпілих, проведення якого тепер має здійснюватися за абсолютно новими стандартами.

У судовому розгляді першою стороною, яка має право допитати свідка $\epsilon$ сторона, за ініціативою якої він був викликаний. У повноваження суду входить лише контроль та забезпечення порядку судового засідання, лише за клопотанням сторони суд уповноважений знімати з розгляду питання, що не стосуються предмету кримінального провадження (справи).

Суд у допиті не бере участі, він може лише відвести поставлене стороною запитання. Кожна із сторін сама допитує представлених нею свідків прямий допит (головний допит), залишаючись в межах тих обставин, які вона бажає довести показами даного свідка; після головного допиту починається протилежний або перехресний допит під час якого дозволяється задавати навідні запитання [3, с. 325].

В ході підготовки до допиту, якщо існує така можливість, необхідно вивчити соціально-демографічні дані, психологічні, психофізіологічні якості і стан допитуваної особи. Зрозуміло, заздалегідь важко передбачити, знання яких саме якостей і станів особистості потрібне в ході допиту, проте в будь якому разі бажано мати уявлення про такі особливості особистості допитуваного, як стать, вік, освіта, професія, інтереси, рівень культури, погляди, психологічні якості (характер, темперамент, воля, емоційні риси), можливі психологічні стани в момент допиту (розгубленість, пригніченість, страх, самовпевненість 178 
тощо). Весь хід допиту можна умовно уявити як тактичну боротьбу двох сторін із протилежними інтересами [4, с. 285].

Головне завдання учасників допиту полягає у допомозі особі, що дає показання відновити максимально точно об'єктивну картину минулої події за допомогою тактичних прийомів і методів. Цікавим, наприклад, видається той факт, що жінки більше схильні до навіювання, емоційніше реагують на аргументи протилежної сторони та реальніше сприймають можливість притягнення їх до кримінальної відповідальності за надання завідомо неправдивих показань. Крім того, жінки практично завжди зосереджують свою увагу на емоційному стані осіб, що були учасниками кримінального правопорушення та здатні запам'ятовувати певні деталі, у той час як чоловіки більш схильні сприймати зовнішню сторону події та відтворювати іiі картину максимально повно.

Однією 3 особливостей перехресного допиту $є$ проведення його безпосередньо у судовому засіданні. Саме показання свідка в ході проведення перехресного допиту надають суддї впевненість в існуванні досліджуваних фактів, оскільки дані, отримані на стадії досудового розслідування ще такими не являються та потребують свого підтвердження в ході судового засідання. Судові факти встановлюються в процесі судового слідства, тому будь які показання можуть претендувати на статус доказів лише після проведення перехресного допиту. Внутрішнє переконання судді складається в ході судового засідання по мірі дослідження доказів, саме при перехресному допиті у нього $є$ можливість віднести їх до достовірних або помилкових.

\section{Література:}

1. Костюченко О.Ю. Особливості проведення прямого та перехресного судового допиту свідків і потерпілих. Вісник кримінального судочинства. № 1/2015. С. 66-73.

2. Зейкан Я. П. Методика перехресного допиту в суді. Х. : Фактор, 2016. $192 \mathrm{c}$.

3. Бабунич В. Суть та значення перехресного допиту. Процесуальні особливості проведення перехресного допиту при розгляді кримінальної справи в суді. Вісник Львівського університету. 2011. Випуск 53. С. 322-328.

4. Валерія Чернецька. Види судових допитів у кримінальному процесі України. Кримінальний процес. 3/2021. С. 284-288. 